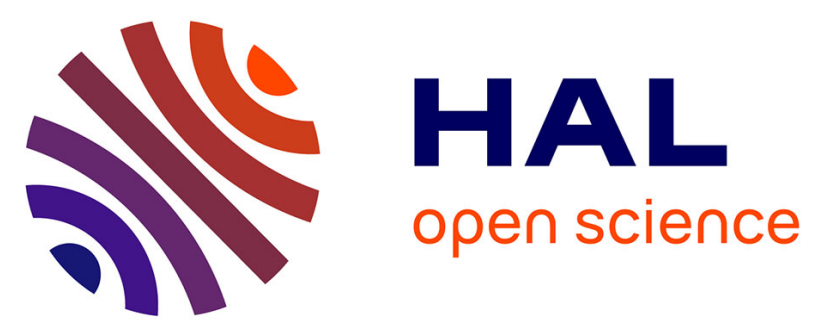

\title{
Nasopharyngeal bacterial colonization during the first wheezing episode is associated with longer duration of hospitalization and higher risk of relapse in young children
}

T. Jartti, S. Kuneinen, P. Lehtinen, V. Peltola, T. Vuorinen, M. Leinonen, O. Ruuskanen

\section{To cite this version:}

T. Jartti, S. Kuneinen, P. Lehtinen, V. Peltola, T. Vuorinen, et al.. Nasopharyngeal bacterial colonization during the first wheezing episode is associated with longer duration of hospitalization and higher risk of relapse in young children. European Journal of Clinical Microbiology and Infectious Diseases, 2010, 30 (2), pp.233-241. 10.1007/s10096-010-1075-z . hal-00631674

\author{
HAL Id: hal-00631674 \\ https://hal.science/hal-00631674
}

Submitted on 13 Oct 2011

HAL is a multi-disciplinary open access archive for the deposit and dissemination of scientific research documents, whether they are published or not. The documents may come from teaching and research institutions in France or abroad, or from public or private research centers.
L'archive ouverte pluridisciplinaire HAL, est destinée au dépôt et à la diffusion de documents scientifiques de niveau recherche, publiés ou non, émanant des établissements d'enseignement et de recherche français ou étrangers, des laboratoires publics ou privés. 


\section{Nasopharyngeal bacterial colonization during the first wheezing episode is associated with longer duration of hospitalization and higher risk of relapse in young children}

Tuomas Jartti, ${ }^{1}$ Susanna Kuneinen, ${ }^{1}$ Pasi Lehtinen, ${ }^{1}$ Ville Peltola, ${ }^{1}$ Tytti Vuorinen, ${ }^{2}$ Maija Leinonen, ${ }^{3}$ Olli Ruuskanen ${ }^{1}$

${ }^{1}$ Department of Pediatrics, Turku University Hospital, Turku; ${ }^{2}$ Department of Virology, University of Turku, Turku; ${ }^{3}$ National Institute of Health and Welfare, Oulu, all in Finland.

Running head: Bacterial colonization and wheezing

Correspondence to: Dr. Tuomas Jartti, Department of Pediatrics, Turku University Hospital, P.O. Box 52, 20520 Turku, Finland. Phone: +358 407270 284. Email: tuomas.jartti@utu.fi. Fax: +358 23131460 .

Supported by the Academy of Finland (Grants 114034 and 132595), the Finnish Cultural Foundation, the Turku University Foundation, the Foundation for Pediatric Research, the Foundation for Out-patient Research, and the Paulo Foundation.

Conflict of interest: none.

Key words: asthma; child; bacterial colonization; wheezing.

Word count of the text: 3053 . 
Objective: To study the association between bacterial colonization/infection and respiratory outcomes in <3-year-old children hospitalized for their first wheezing episode.

Methods: This was an observational study. The primary outcome was a hospitalization time and the secondary outcomes included relapses within 2 months and time to recurrent wheezing (i.e. 3 physician confirmed wheezing episodes) within 12 months. Bacterial antibody assays for Streptococcus pneumoniae, Haemophilus influenzae, Moraxella catarrhalis, Mycoplasma pneumoniae and Chlamydia pneumoniae, nasopharyngeal bacterial culture for the 3 former and urine pneumococcal antigen were studied.

Results: Nasopharyngeal bacterial culture was positive in 31/52 (60\%) children, serologic evidence of bacterial infection was found in 17/96 (18\%) children, urine pneumococcal antigen was positive in 24/101 (24\%), and any bacterial detection method was positive in 53/106 (50\%) children. The children with positive nasopharyngeal bacterial culture had longer duration of hospitalization (hazard ratio 2.4) and more often relapse within two months than those with negative culture (odd's ratio 7.3).

Conclusion: In this study, a half of the first time wheezing children had bacterial colonization or symptomatic or asymptomatic bacterial infection. The bacterial colonization (i.e. positive nasopharyngeal bacterial culture) was associated with longer duration of hospitalization and higher risk of recurrent wheezing.

Word count of the abstract: 196. 


\section{Introduction}

Acute wheezing illnesses in children are almost exclusively associated with respiratory viral infection $(1,2)$. Symptoms are mainly caused by the host immune response to infection, although a direct cytopathic effect of the virus may also contribute (3).

Bacterial etiology of acute wheezing has been studied in the past and the negative results as well as no effect from antibiotics have reduced the amount of more recent studies. Evidence of bacteria in the upper airways of children has been found using culture or serology in up to $40 \%$ of wheezing children (4-6). These have included Streptococcus pneumoniae (S Pne), Haemophilus influenzae (H infl), Moraxella catarrhalis (M cat), Mycoplasma pneumoniae (M pne) and Chlamydia pneumoniae (C pne). Approximately a half of wheezing children have had clinical signs of possible bacterial complication (otitis $44 \%$, alveolar infiltrates $10 \%$, or sinusitis $17 \%)$; highest numbers $(>70 \%)$ are for acute otitis media infections in the cases of respiratory syncytial virus induced bronchiolitis (7).

The reports on the association between bacterial colonization of the airway and severity of illness are scarce. One study found that children with recurrent wheezing and coexistent bacterial colonization and virus infection presented longer duration of hospitalization than those with virus infection but without bacterial colonization (8). Interestingly, the risk for recurrent wheezing or asthma has been linked, not only to viral etiology of early wheezing as shown in many studies, but also to bacterial colonization of asymptomatic neonates in one other study (9-13). Of the latter, hypopharyngeal colonization with $\mathrm{S}$ pne, $\mathrm{H}$ infl and/or M cat at age one month has predicted recurrent wheezing and asthma at age 5 years in a birth cohort born to mothers with asthma (13). Moreover, patients with asthma may be more susceptible to serious pneumococcal disease $(14,15)$.

The understanding of the significance of bacterial colonization and/or infection in young wheezing children is likely to give clinically relevant information that could help in understanding the risk of recurrent wheezing and in designing early prevention and treatment strategies. Therefore, we studied specific findings of bacterial colonization/infections in less 
than 3-year-old children hospitalized for their first wheezing episode, and how these findings were associated with the duration of initial hospitalization and occurrence of recurrent wheezing in a 12-month follow-up. 


\section{Methods}

Subjects

This cross-sectional study is a substudy of the VINKU study which took place in the Department of Pediatrics of Turku University Hospital (9/2000-5/2002). Its original aim was to study the efficacy of oral prednisolone in hospitalized wheezing children in relation to viral etiology, i.e. a half of the patients were randomized to receive oral prednisolon for 3 days and the other half placebo in a double blind design (first dose $2 \mathrm{mg} / \mathrm{kg}$, then $2 \mathrm{mg} / \mathrm{kg} / \mathrm{d}$ in 3 divided doses). The methods have been described earlier $(7,16,17)$. The present study included all children of the VINKU study that had their first wheezing episode and age $3-35$ months (Fig. 1). Predefined exclusion criteria were chronic disease (other than asthma or allergy), systemic glucocorticoid treatment within 4 weeks prior to the study, severe wheezing necessitating intensive care unit treatment, and previous participation in this study. Here, we only included children aged $<3$ years and experiencing their first wheezing episode since 12 month follow-up data was only available from them. Other children were only followed up to 2 months. The study protocol was approved by the Ethics Committee of the Turku University Hospital and informed consent was obtained from the guardian before commencing the study.

\section{Definitions}

Atopy was defined as positive immunoglobulin ( $\mathrm{Ig}) \mathrm{E}$ antibodies to any of the common allergens (cut-off level $0.35 \mathrm{kU} / \mathrm{L}$ for codfish, cow's milk, egg, peanut, soybean, wheat, cat, dog, horse, birch, mugwort, timothy, Cladosporium herbarum and Dermatophagoides pteronyssinus; fluoro-enzyme immunoassay, CAP FEIA, Phadiatop Combi ${ }^{\circledR}$, Phadia, Uppsala, Sweden). Aeroallergen sensitization was defined as positive $\operatorname{IgE}$ antibodies to any of the latter 8 allergens. Perennial aeroallergen sensitization was defined as positive IgE antibodies to dog, cat or Dermatophagoides pteronyssinus. Birch, mugwort, timothy and Cladosporium herbarum were considered as seasonal aeroallergens. Eczema was diagnosed by physician and referred as atopic eczema if any sensitization was present. 


\section{Outcome measures}

The predefined primary outcome was the time until ready for discharge (hospitalization time), which was defined as a duration of respiratory symptoms score $\geq 3$ during the hospital stay. The respiratory symptoms score, which was assessed every 12 hours during hospitalization, is a summed score for the degree of dyspnea $(0=$ none, $1=$ mild, $2=$ moderate, $3=$ severe $)$, type of breathing $(0=$ normal, $1=$ use of stomach muscles, 2 = use of intercostal muscles, 3 = nasal flaring), severity of auscultatory findings on wheezing $(0=$ none, $1=$ expiratory, $2=$ inspiratory and expiratory, $3=$ audible without stethoscope) and assessment of expiratory:inspiratory time ( $0=1: 2,1$ $=1: 1,2=2: 1,3=3: 1)$. An estimation of 6 hours was used for the last 12 -hour period between hospital assessments, i.e. the period during which the patient became ready for discharge. The predefined secondary outcomes were clinic visits for recurrent wheezing during a 2-month period after the discharge for all recruited subjects $(n=293)$ and time to recurrent wheezing (i.e. 3 physician confirmed wheezing episodes) within 12 months after discharge for the first-time wheezing children $(n=131)(11,16,17)$. In this observational study, we report the associations between specific findings of bacterial colonization/infections and clinical outcomes of the study.

Sample collection and analysis

On admission, a nasopharyngeal aspirate sample was obtained using a standardized procedure, as described previously (18). Blood samples were collected at study entry and 2-3 weeks later, and analysed as previously described $(11,16,17)$. Urine samples were collected at study entry. Culture and antigen analyses were done on fresh samples. Otherwise, samples were stored in $-70{ }^{\circ} \mathrm{C}$ for later analysis. Bacterial antibody assays to confirm acute $\mathrm{S}$ pne, $\mathrm{H}$ inf, $\mathrm{M}$ cat, $\mathrm{M}$ pne and $\mathrm{C}$ pne infection were performed on acute and convalescent serum samples as described previously (7). Urine pneumococcal antigen and nasopharyngeal bacterial cultures ( $\mathrm{S}$ pne, $\mathrm{H}$ inf, or $\mathrm{M}$ cat) were analyzed according to the standard clinical routine of the Central Laboratory, Turku University Hospital, Turku, Finland. 
Nasopharyngeal bacterial cultures were added to the protocol in the middle of the study and obtained only from the second study year. Other methods of the study have been previously described $(2,16-18)$.

\section{Statistics}

No statistical power calculation was done for this analysis. Kolmogorov-Smirnov test was used to test the normality of data distributions. In the analysis of baseline data, MannWhitney U test was used for continuous data since data distributions were skewed, and Chisquare test or Fischer's exact test (when counts $<5$ ) were used for categoric data. The outcome data was analysed using Cox or logistic regression analyses. The analyses including bacterial serology were repeated with adjustment to prednisolon treatment due to baseline difference. The statistical analyses were carried out using SPSS/ PC 13.0 software (SPSS Inc, Chicago, IL, USA). 


\section{Results}

Data set

Of the 293 randomized patients, 131 children fulfilled the criteria for the long-term followup, i.e. the first episode and age 3 - 35 months (Fig. 1). Lost to follow-up were 13 children. Thus, 118 children completed the follow-up. Eleven children (9\%) were treated for prolonged cough with a continuous inhaled corticosteroid (by non-study physicians) and were excluded from analyses because of unclear diagnosis. Of the final study cohort $(n=107), 87$ children were clinically examined and their parents personally interviewed at 12-month follow-up visit, and the parents of 20 children were interviewed by phone.

\section{Patient characteristics}

The median age of the final study cohort was 1.1 years (range $0.3,2.9$ ). Table 1 shows the characteristics of the study children. Nasopharyngeal bacterial culture (S pne, H inf, or M cat) was positive in 31 of $52(60 \%)$ children, serologic evidence of bacterial infection (S pne, M pne, C pne, H inf, or M cat) was found in 17 of 96 (18\%) children, urine pneumococcal antigen was positive in 24 of $101(24 \%)$ children, and evidence of bacterial colonization or infection by any bacterial detection method was found in 53 of the $106(50 \%)$ children (Table 2). Of the 107 children, 100 (93\%) had a viral infection. Most common findings were as follows: RSV (46\%), rhinovirus (29\%), human bocavirus (23\%), enteroviruses (16\%) and $\geq 2$ viruses $(40 / 107,37 \%)$. No significant differences were found in patient characteristics between nasopharyngeal bacterial culture + vs. - , bacterial serology + vs. -, or urine pneumococcal antigen detection + vs. - groups except that the children who received prednisolone had more often positive bacterial serology $(14 / 47,30 \%)$ than those receiving placebo $(3 / 49,6 \%, P=0.0029)$ (data shown for nasopharyngeal bacterial culture + vs. groups in Table 3; otherwise data not shown). 


\section{Hospitalization Time}

The median hospitalization time in children with positive vs. negative nasopharyngeal bacterial culture was 48 h (innerquartile range 24,$64 ; n=31)$ vs. 18 h $(12,27 ; n=$ 21 ). The difference was significant (univariable hazard ratio $2.38 ; 95 \%$ confidence interval 1.32, 4.36;P=0.004) (Fig. 2A).

Relapse within two months

Children positive for nasopharyngeal bacterial culture were more often readmitted to an outpatient clinic within two months due to recurrent wheezing than those with negative culture. Thirteen of 30 (43\%) children with positive nasopharyngeal bacterial culture had a relapse compared to 2 of 21 (10\%) children with negative nasopharyngeal bacterial culture (univariable analysis, $P=0.017$, Table 4).

Recurrent wheezing within 12 months

Eleven of 31 (35\%) children positive for nasopharyngeal bacterial culture and 5 of 21 (24\%) children negative for nasopharyngeal bacterial culture had recurrent wheezing within a year (univariable analysis $P=0.49$, Fig. 2B). Nine of 17 (53\%) children positive for bacterial serology and 28 of 79 (35\%) children negative for bacterial serology had recurrent wheezing within a year (univariable analysis $P=0.11$, multivariable analysis including prednisolon treatment, $P=0.18$, Fig. 2C). No other significant differencies or tendencies were found. 


\section{Discussion}

This study showed that bacterial colonization or asymptomatic or symptomatic bacterial infection can be demonstrated in a half of the young children experiencing their first wheezing episode. Moreover, children with positive nasopharyngeal bacterial culture, an indication of bacterial colonization, had a prolonged hospitalization time and more often relapse within 2 months after discharge. Since there were no differences in many baseline characteristics of patients between bacterial culture positive and negative groups, we only used univariate analysis in bacterial colonization data.

Our prevalence numbers for bacterial colonization and infection are comparable to previous studies on normal and wheezing children $(4,6,19-22)$. In wheezing children, Nagayama et al. (2007) reported the prevalence of $17 \%$ for S pne, $\mathrm{H}$ infl and $\mathrm{M}$ cat cultured from sputum samples (6). Serologic evidence for M pne infection has ranged from $4 \%$ to $23 \%$ and for C pne from $3 \%$ to $17 \%$ in children with acute wheezing $(4,19,22)$. Serologic evidence of $\mathrm{H}$ infl and $\mathrm{M}$ cat has been $<5 \%$ in wheezing children (19). The antigenuria for $\mathrm{S}$ pne was quite high in our study (24\%) in contrast to one previous study (1\%) (20).

We did not find association to age, but other studies suggest that nasopharyngeal colonization of respiratory bacteria increase after birth and peak during early childhood, and then steadily decrease $(6,13,23,24)$. Although there is variability in the peak age during childhood between studies, the nasopharyngeal colonization is much less during early adulthood compared to childhood $(23,25)$. An increase in respiratory bacterial colonization has been associated with low socio-economic status, autumn-winter seasons, exposure to other children, prone sleeping position, upper respiratory or otitis media infection, immunosuppression or lack of immunization, use of pacifiers, hospitalization and xylitol consumption $(21,24,26)$. Allergy has been found to be associated with $\mathrm{S}$ pne and $\mathrm{H}$ infl carriage in children $(27,28)$. No association or controversial association has been found with gender, diet and parental smoking $(5,6,13,21,24-26)$. Of the factors listed above, we did not find an association between bacterial colonization and atopy, atopic eczema, gender, season, older siblings/day-care, or parental smoking. Children with positive bacterial 
serology (i.e. indication of symptomatic or asymptomatic infection), however, had more often prednisolone treatment. Although we could not show link between age and bacterial seroconversion, $\mathrm{M}$ pne or $\mathrm{C}$ pne seroconversion associated wheezing may increase by age (4).

Poorer prognosis in children with nasopharyngeal bacterial carriage is in line with one previous study which showed that hypopharyngeal colonization with $\mathrm{S}$ pne, $\mathrm{H}$ infl, and/or $\mathrm{M}$ cat in asymptomatic neonates at 1 month of age was associated with increased risk of a first wheezy episode, persistent wheeze, acute severe exacerbation of wheeze, hospitalization for wheeze, increased blood eosinophil counts and total $\operatorname{IgE}$ and, eventually, increased reversibility of airway resistance and development of asthma by the age of 5 years (13). Interestingly, atopy was not connected with the influence of bacterial findings on prognosis either in our study nor in the previous study (13). In another study, the frequency of bacterial colonization in children with recurrent wheezing was higher than that of children with bronchiolitis, which is in line with our results (8). Moreover, among the cases with recurrent wheezing, children who had coexisted non-invasive bacterial colonization and virus infection presented more frequent cyanosis, longer duration of hospitalization, higher concentration of IL-10, and higher percentage of neutrophil compared with children with virus infection but without bacterial colonization. In a population-based study on adolescents, pneumococcal colonization was independently associated with a history of an exacerbation of asthma during the preceding year (25). The association to allergies was not reported.

The causal direction of the association between nasopharyngeal bacterial colonization and respiratory outcome is unknown: are bacteria triggering susceptible individuals to recurrent wheeze, (13) or are children predisposed to recurrent wheeze more susceptible to bacteria as part of such constitution $(14,15)$ ? Susceptibility to recurrent wheezing is associated with preexisting airway inflammation, altered host defenses and increased risk to bacterial or viral infections or their carriage. Both airway inflammation and decreased resistance for microbes probably predispose for more severe illness and poorer long-term outcome. A normal local immune response to an organism would prevent colonization and limit its duration $(21,29)$. In general, mucosal immunity matures earlier than systemic immunity, and therefore, 
bacterial colonization pattern may be a first sign of biased immune functions $(21,26)$. These suggestions are supported by studies showing that asthmatics have increased risk for serious pneumococcal infection $(14,15,30)$. An inability of asthma prone children to resist bacterial infections may also be comparable to their inability to limit viral infections to the upper respiratory tract $(1,2)$. This increased susceptibility to lower respiratory tract viral infections has been shown to relate to defective innate immune responses $(31,32)$. Moreover, bacterial and virus infections may have synergistic actions due to the destruction of respiratory epithelium by viral infection which may increase bacterial adhesion, due to the possible virus-induced immunosuppression which may cause more severe bacterial infections, and/or due to the inflammatory response to viral infection which may up-regulate expression of molecules that bacteria utilize as receptors (33). We, however, speculate that bacterial colonization is probably just a "by-stander" factor since it was not linked to most distant outcome, recurrent wheezing, in our study.

Antibiotic treatment did not influence the prognosis in our study. This is in line with general consideration that antibiotics do not effectively eradicate bacterial colonization from the nasopharynx (21). The reduction in carriage is considered only temporary. Antibiotics induce suppression of susceptible bacteria, but after antibiotic treatment, a rapid replacement of strains usually occurs with either overgrowth of more resistant strains that were masked by other organisms or by newly acquired resistant strains. Although our study was not properly designed to answer the effect of antibiotic treatment (antibiotic use was decided on clinical bases), our results are in agreement with Kusel et al. (2008), who did not find association between the receipt of antibiotics in the first year of life and subsequent development of atopy, current wheeze or asthma at age 5 years (34). Overall, prognosis being independent of antibiotic treatment further supports the hypothesis that bacteria in predisposed children are most likely just by-standers indicating high risk individuals. Possible interventions should not primarily be directed against the microbe, instead they should be designed to reduce the underlying inflammatory condition predisposing to an infection or colonization. Interestingly, our finding of increased prevalence of bacterial seropositivity in the prednisolone group raises naturally a question whether systemic corticosteroids even with therapeutic doses could 
increase the risk of bacterial infections. However, short courses of systemic corticosteroids have been found safe in the treatment of childhood wheezing (35).

Our study has some limitations. Since nasopharyngeal bacterial colonization increases significantly during acute respiratory infections, we can not differentiate bacterial colonization from asymptomatic or symptomatic bacterial infection in our study (21). However, positive findings in nasopharyngeal bacterial culture or urine pneumococcal antigen detection are usually considered as an indication of bacterial colonization, and seroconversion as an indication of symptomatic or asymptomatic infection. Isolation of a potential bacterial pathogen from upper respiratory secretions does not exactly reflect infection of the lower airways. Instead, bronchoalveolar lavage sampling is considered as the most optimum methods for lower airway colonization since it is believed to be sterile. In agreement with our findings, bacteria and increased numbers of inflammatory cells have been reported in bronchoalveolar lavage fluid in wheezing and asthmatic children (36-39). The follow-up period was limited to 12-months, and data were only available from children experiencing their first wheezing episode. Nasopharyngeal bacterial cultures where obtained only from the second study year which explains their low number. Comparisons were done within wheezing children and there was no healthy control group. Sample size was rather small, and no statistical power analysis was not done since this was a post hoc analysis.

In conclusions, bacterial colonization and/or infection was found in a half of the children with acute wheezing in this study. Most importantly, the bacterial colonization was associated with prolonged hospitalization and increased risk of relapse, which is a new finding. Since the prevalences of traditional risk factors of recurrent wheeze/asthma in young children, any sensitization and especially aeroallergen sensitization, are low during infancy, new risk markers are needed $(41,42)$. Nasopharyngeal bacterial colonization could serve as a new and early marker for those at an increased risk for a relapse. This data provides preliminary evidence for doing a larger prospective study. 


\section{References}

1. Heymann PW, Carper HT, Murphy DD, Platts-Mills TA, Patrie J, McLaughlin AP, et $a l$. Viral infections in relation to age, atopy, and season of admission among children hospitalized for wheezing. J Allergy Clin Immunol 2004;114(2):239-47.

2. Allander T, Jartti T, Gupta S, Niesters H, Lehtinen P, Österback R, et al. Human bocavirus and acute wheezing in children. Clin Infect Dis 2007;44(7):904-10.

3. Bruder D, Srikiatkhachorn A, Enelow RI. Cellular immunity and lung injury in respiratory virus infection. Viral Immunol 2006;19(2):147-55.

4. Esposito S, Blasi F, Arosio C, Fioravanti L, Fagetti L, Droghetti R, et al. Importance of acute Mycoplasma pneumoniae and Chlamydia pneumoniae infections in children with wheezing. Eur Respir J 2000; 16(6):1142-6.

5. Normann E, Gnarpe J, Wettergren B, Janson C, Wickman M, Nordvall L. Association between Chlamydia pneumoniae antibodies and wheezing in young children and the influence of sex. Thorax 2006;61(12):1054-8.

6. Nagayama Y, Tsubaki T, Nakayama S, Sawada K, Taguchi K, Toba T, et al. Bacterial colonization in respiratory secretions from acute and recurrent wheezing infants and children. Pediatr Allergy Immunol 2007;18(2):110-7.

7. Lehtinen P, Jartti T, Virkki R, Vuorinen T, Leinonen M, Peltola V, et al. Bacterial coinfections in children with viral wheezing. Eur J Clin Microbiol Infect Dis 2006;25(7):463-9.

8. Yu D, Wei L, Zhengxiu L, Jian L, Lijia W, Wei L, et al. Impact of bacterial colonization on the severity and airway inflammation of children with virus induced wheezing. Clin Microbiol Infect 2009. [Epub ahead of print]

9. Kotaniemi-Syrjänen A, Vainionpää R, Reijonen TM, Waris M, Korhonen K, Korppi M. Rhinovirus-induced wheezing in infancy--the first sign of childhood asthma? J Allergy Clin Immunol 2003;111(1):66-71.

10. Lemanske RF, Jackson DJ, Gangnon RE, Evans MD, Li Z, Shult PA, et al. Rhinovirus illnesses during infancy predict subsequent childhood wheezing. J Allergy Clin Immunol 2005;116(3):571-7. 
11. Lehtinen P, Ruohola A, Vuorinen T, Vanto T, Ruuskanen O, Jartti T. Prednisolone reduces recurrent wheezing after a first wheezing episode associated with rhinovirus infection or eczema. J Allergy Clin Immunol 2007;119(3):570-5.

12. Kusel MM, de Klerk NH, Kebadze T, Vohma V, Holt PG, Johnston SL, et al. Earlylife respiratory viral infections, atopic sensitization, and risk of subsequent development of persistent asthma. J Allergy Clin Immunol 2007;119(5):1105-10.

13. Bisgaard H, Hermansen MN, Buchvald F, Loland L, Halkjaer LB, Bønnelykke K, et al. Childhood asthma after bacterial colonization of the airway in neonates. N Engl J Med 2007;357(15):1487-95.

14. Talbot TR, Hartert TV, Mitchel E, Halasa NB, Arbogast PG, Poehling KA, et al. Asthma as a risk factor for invasive pneumococcal disease. $\mathrm{N}$ Engl $\mathrm{J}$ Med 2005;352(20):2082-90.

15. Juhn YJ, Kita H, Yawn BP, Boyce TG, Yoo KH, McGree ME, et al. Increased risk of serious pneumococcal disease in patients with asthma. J Allergy Clin Immunol 2008;122(4):719-23.

16. Jartti T, Lehtinen P, Vanto T, Hartiala J, Vuorinen T, Mäkelä MJ, et al. The efficacy of prednisolone in early wheezing induced by rhinovirus or respiratory syncytial virus. Pediatr Infect Dis J 2006;25(6):482-8.

17. Jartti T, Lehtinen P, Vanto T, Vuorinen T, Hartiala J, Hiekkanen H, et al. Efficacy of prednisolone in children hospitalized for recurrent wheezing. Pediatr Allergy Immunol 2007;18(4):326-34.

18. Jartti T, Lehtinen P, Vuorinen T, Österback R, van den Hoogen B, Osterhaus AD, et al. Respiratory picornaviruses and respiratory syncytial virus as causative agents of acute expiratory wheezing in children. Emerg Infect Dis 2004;10(6):1095-101.

19. Mertsola J, Ziegler T, Ruuskanen O, Vanto T, Koivikko A, Halonen P. Recurrent wheezy bronchitis and viral respiratory infections. Arch Dis Child 1991;66(1):124-9.

20. Korppi M, Leinonen M, Koskela M, Mäkelä PH, Saikku P, Launiala K. Bacterial infection in under school age children with expiratory difficulty. Pediatr Pulmonol 1991;10(4):254-9. 
21. García-Rodríguez JA, Fresnadillo Martínez MJ. Dynamics of nasopharyngeal colonization by potential respiratory pathogens. J Antimicrob Chemother 2002;50(Suppl S2):59-73.

22. Ong BH, Gao Q, Phoon MC, Chow VT, Tan WC, Van Bever HP. Identification of human metapneumovirus and Chlamydophila pneumoniae in children with asthma and wheeze in Singapore. Singapore Med J 2007;48(4):291-3.

23. Watson K, Carville K, Bowman J, Jacoby P, Riley TV, Leach AJ, et al. Upper respiratory tract bacterial carriage in Aboriginal and non-Aboriginal children in a semi-arid area of Western Australia. Pediatr Infect Dis J 2006;25(9):782-90.

24. Harrison LM, Morris JA, Telford DR, Brown SM, Jones K. The nasopharyngeal bacterial flora in infancy: effects of age, gender, season, viral upper respiratory tract infection and sleeping position. FEMS Immunol Med Microbiol 1999;25(1-2):19-28.

25. Cardozo DM, Nascimento-Carvalho CM, Andrade AL, Silvany-Neto AM, Daltro CH, Brandão MA, et al. Prevalence and risk factors for nasopharyngeal carriage of Streptococcus pneumoniae among adolescents. J Med Microbiol 2008;57(Pt 2):185-9.

26. Ghaffar F, Friedland IR, McCracken GH Jr. Dynamics of nasopharyngeal colonization by Streptococcus pneumoniae. Pediatr Infect Dis J 1999;18(7):638-46.

27. Borer A, Meirson H, Peled N, Porat N, Dagan R, Fraser D, et al. Antibiotic-resistant pneumococci carried by young children do not appear to disseminate to adult members of a closed community. Clin Infect Dis 2001;33(4):436-44.

28. St Sauver J, Marrs CF, Foxman B, Somsel P, Madera R, Gilsdorf JR. Risk factors for otitis media and carriage of multiple strains of Haemophilus influenzae and Streptococcus pneumoniae. Emerg Infect Dis 2000;6(6):622-30.

29. Faden H, Duffy L, Williams A, Krystofik DA, Wolf J. Epidemiology of nasopharyngeal colonization with nontypeable Haemophilus influenzae in the first 2 years of life. J Infect Dis 1995;172(1):132-5

30. Hartert TV. Are persons with asthma at increased risk of pneumococcal infections, and can we prevent them? J Allergy Clin Immunol 2008;122(4):724-5.

31. Johnston SL. Innate immunity in the pathogenesis of virus-induced asthma exacerbations. Proc Am Thorac Soc 2007;4(3):267-70. 
32. Holt PG, Upham JW, Sly PD. Contemporaneous maturation of immunologic and respiratory functions during early childhood: implications for development of asthma prevention strategies. J Allergy Clin Immunol 2005;116(1):16-24.

33. Peltola VT, McCullers JA. Respiratory viruses predisposing to bacterial infections: role of neuramidase. Pediatr Infect Dis J 2004;23(1 Suppl):S87-97.

34. Kusel MM, de Klerk N, Holt PG, Sly PD. Antibiotic use in the first year of life and risk of atopic disease in early childhood. Clin Exp Allergy 2008;38(12):1921-8.

35. Jartti T, Vanto T, Heikkinen T, Ruuskanen O. Systemic glucocorticoids in childhood expiratory wheezing: relation between age and viral etiology with efficacy. Pediatr Infect Dis J 2002;21:873-8.

36. Marguet C, Jouen-Boedes F, Dean TP, Warner JO. Bronchoalveolar cell profiles in children with asthma infantile wheeze, chronic cough, or cystic fibrosis. Am J Respir Crit Care Med 1999:159(5 Pt 1):1533-40.

37. Fayon M, Just J, Thien HV, Pascual L, Sandouk G, Grimfeld A. Bacterial flora of the lower respiratory tract in children with bronchial asthma. Acta Paediatr 1999:88(11):1216-22.

38. Krawiec ME, Westcott JY, Chu HW, Balzar S, Trudeau JB, Schwartz LB, et al. Persistent wheezing in very young children is associated with lower respiratory inflammation. Am J Respir Crit Care Med 2001;163(6):1338-43.

39. Le Bourgeois M, Goncalves M, Le Clainche L, Benoist MR, Fournet JC, Scheinmann $\mathrm{P}$, et al. Bronchoalveolar cells in children $<3$ years old with severe recurrent wheezing. Chest 2002;122(3):791-7.

40. National Heart, Lung and Blood Institute. Expert Panel Report 3 (EPR3): Guidelines for the Diagnosis and Management of Asthma. http://www.nhlbi.nih.gov/guidelines/asthma/asthgdln.htm

41. Illi S, von Mutius E, Lau S, Niggemann B, Grüber C, Wahn U, et al. Perennial allergen sensitisation early in life and chronic asthma in children: a birth cohort study. Lancet 2006;368(9537):763-70.

42. Jartti T, Lehtinen P, Vuorinen T, Ruuskanen O. Bronchiolitis: age and previous wheezing episodes are linked to viral etiology and atopic characteristics. Pediatr Infect Dis J 2009;28(4):311-7. 


\section{Legends to the figures}

Figure 1. Study flow chart.

Figure 2. A. The Kaplan-Meier plot of the hospitalization time in the first-time wheezing children with positive (bolded line) and negative nasopharyngeal bacterial culture (dashed line). Univariable hazard ratio $2.38 ; 95 \%$ confidence interval $1.32,4.36$. B. Time to recurrent wheezing (i.e. 3 physician confirmed wheezing episodes) within 12 months in the first-time wheezing children with positive (bolded line) and negative nasopharyngeal bacterial culture (dashed line). Univariable hazard ratio $1.46 ; 95 \%$ confidence interval 0.50, 4.28. C. Time to recurrent wheezing within 12 months in the first-time wheezing children with positive (bolded line) and negative bacterial serology (dashed line). Univariable hazard ratio 1.86; $95 \%$ confidence interval $0.88,3.95$. See text for details. 
Table 1. Patient characteristics.

\begin{tabular}{|c|c|}
\hline Factor & $\underline{\mathrm{n}=107}$ \\
\hline Age, years & $1.0(0.5 ; 1.5)$ \\
\hline Male gender & $72(67 \%)$ \\
\hline Prematurity & $18(17 \%)$ \\
\hline Eczema & $\underline{34 / 106(32 \%)}$ \\
\hline Atopic eczema, No (\%) & $7 / 104(7 \%)$ \\
\hline Atopy, No (\%) ${ }^{1}$ & 18/105(17\%) \\
\hline Food sensitization, No (\%) & $\underline{18 / 105(17 \%)}$ \\
\hline Aeroallergen sensitization, No (\%) & $2 / 105(2 \%)$ \\
\hline Perennial, No (\%) & $1 / 105(1 \%)$ \\
\hline Seasonal, No (\%) & $2 / 105(2 \%)$ \\
\hline B-Eos, x $10^{9} / \mathrm{L}$ & $\underline{0.1(0 ; 0.4)}$ \\
\hline B-Eos $\geq 0.4 \times 10^{9} / \mathrm{L}$ & $19 / 106(18 \%)$ \\
\hline Rhinovirus, No & $31(29 \%)$ \\
\hline Respirtory syncytial virus, No & $49(46 \%)$ \\
\hline Enterovirus, No & $17(16 \%)$ \\
\hline Bocavirus, No & $25(23 \%)$ \\
\hline Mixed viral infection, No. & $40(37 \%)$ \\
\hline Exhaled nitric oxide, $p p b$ & $\underline{5.4(3.8,8.8)}$ \\
\hline Parental asthma, No (\%) & $18 / 106(17 \%)$ \\
\hline Parental allergy, No (\%) & $\underline{55 / 106(52 \%)}$ \\
\hline Parental smoking, No (\%) & $45 / 106(43 \%)$ \\
\hline Older sibling or day care, No (\%) & $93(87 \%)$ \\
\hline Antibiotic treatment, No (\%) & $70(65 \%)$ \\
\hline Acute otitis media, No (\%) & $63(59 \%)$ \\
\hline Oral prednisolon, No. & $54(50 \%)$ \\
\hline
\end{tabular}

B-Eos, blood eosinophils; ppb, parts per billion.

Values are shown as medians (interquartile range) or number (\%). 
Table 2. Bacterial findings.

\begin{tabular}{|l|c|}
\hline Bacterial detection positive & $\underline{\mathbf{n}(\%)}$ \\
\hline$\underline{\text { Any nasopharyngeal bacterial culture }}$ & $\underline{31 / 52(60 \%)}$ \\
\hline Streptococcus pneumoniae & $\underline{13 / 52(25 \%)}$ \\
\hline Haemophilus influenzae & $\underline{11 / 52(21 \%)}$ \\
\hline Moraxella catarrhalis & $\underline{16 / 52(31 \%)}$ \\
\hline Any bacterial serology & $\underline{17 / 96(18 \%)}$ \\
\hline Chlamydia pneumoniae & $\underline{2 / 97(2 \%)}$ \\
\hline Mycoplasma pneumoniae & $\underline{5 / 101(5 \%)}$ \\
\hline Streptococcus pneumoniae & $\underline{7 / 97(7 \%)}$ \\
\hline Haemophilus influenzae & $\underline{3 / 97(3 \%)}$ \\
\hline Moraxella catarrhalis & $\underline{2 / 97(2 \%)}$ \\
\hline$\underline{\text { Urine pneumococcal antigen }}$ & $\underline{24 / 101(24 \%)}$ \\
\hline$\underline{\text { Any bacterial detection method }(>1 \text { method done) }}$ & $\underline{53 / 106(50 \%)}$ \\
\hline Streptococcus pneumoniae & $\underline{31 / 106(29 \%)}$ \\
\hline Haemophilus influenzae & $\underline{13 / 101(13 \%)}$ \\
\hline Moraxella catarrhalis & $\underline{17 / 100(17 \%)}$ \\
\hline
\end{tabular}


Table 3. Patient characteristics in children with positive and negative nasopharyngeal bacterial culture.

\begin{tabular}{|c|c|c|c|}
\hline \multirow[t]{2}{*}{ Factor } & \multicolumn{2}{|c|}{$\underline{\text { Nasopharyngeal bacterial culture }}$} & \multirow[t]{2}{*}{$\underline{P}$} \\
\hline & $\begin{array}{l}\text { Positive } \\
\underline{n=31}\end{array}$ & $\begin{array}{l}\text { Negative } \\
\underline{n=21}\end{array}$ & \\
\hline Age, years & $\underline{1.1(0.5 ; 1.5)}$ & $\underline{0.8(0.5 ; 2.0)}$ & $\underline{0.73}$ \\
\hline Male gender & $18(58 \%)$ & $15(71 \%)$ & $\underline{0.33}$ \\
\hline Prematurity & $5(16 \%)$ & $4(19 \%)$ & $\underline{1.00}$ \\
\hline Eczema & $11(35 \%)$ & $\underline{7(33 \%)}$ & $\underline{0.87}$ \\
\hline Atopic eczema, No (\%) & $\underline{3(9.7 \%)}$ & $1(4.8 \%)$ & $\underline{0.51}$ \\
\hline Atopy, No (\%) & $\underline{4(13 \%)}$ & $\underline{2(9.5 \%)}$ & $\underline{0.71}$ \\
\hline Food sensitization, No (\%) & $\underline{4(13 \%)}$ & $2(9.5 \%)$ & $\underline{0.71}$ \\
\hline Aeroallergen sensitization, No (\%) & $2(6.5 \%)$ & $\underline{0(0.0 \%)}$ & $\underline{0.24}$ \\
\hline Perennial, No (\%) & $\underline{1(3.2 \%)}$ & $\underline{0(0.0 \%)}$ & $\underline{0.41}$ \\
\hline Seasonal, No (\%) & $2(6.5 \%)$ & $\underline{0(0.0 \%)}$ & $\underline{0.24}$ \\
\hline B-Eos, x $10^{9} / \mathrm{L}$ & $\underline{0.1(0.0 ; 0.2)}$ & $\underline{0.1(0.1 ; 0.2)}$ & $\underline{0.24}$ \\
\hline$\underline{B}-$ Eos $\geq 0.4 \times 10^{9} / \mathrm{L}$ & $4(13 \%)$ & $\underline{2(9.5 \%)}$ & $\underline{0.71}$ \\
\hline Rhinovirus, No & $7(23 \%)$ & $\underline{4(19 \%)}$ & $\underline{1.00}$ \\
\hline Respirtory syncytial virus, No & $22(71 \%)$ & $13(62 \%)$ & $\underline{0.56}$ \\
\hline Enterovirus, No & $\underline{4 / 29(14 \%)}$ & $\underline{4(19 \%)}$ & $\underline{0.71}$ \\
\hline Bocavirus, No & 5/27(19\%) & $3(14 \%)$ & $\underline{1.00}$ \\
\hline Mixed viral infection, No. & $13(42 \%)$ & $\underline{8(38 \%)}$ & $\underline{0.78}$ \\
\hline Exhaled nitric oxide, ppb & $\underline{5.0(3.8 ; 8.2)}$ & $\underline{5.2(4.0 ; 7.5)}$ & $\underline{0.81}$ \\
\hline Parental asthma, No (\%) & $\underline{5(16 \%)}$ & $5(24 \%)$ & $\underline{0.49}$ \\
\hline Parental allergy, No (\%) & $19(61 \%)$ & $12(57 \%)$ & $\underline{0.76}$ \\
\hline Parental smoking, No (\%) & $16(52 \%)$ & $\underline{10(48 \%)}$ & $\underline{0.78}$ \\
\hline Older sibling or day care, No $(\%)$ & $28(90 \%)$ & $18(86 \%)$ & $\underline{0.61}$ \\
\hline Antibiotic treatment, No (\%) & $24(77 \%)$ & $16(76 \%)$ & $\underline{0.92}$ \\
\hline Acute otitis media, No (\%) & $20(65 \%)$ & $14(67 \%)$ & $\underline{0.87}$ \\
\hline Oral prednisolon, No. & $15(48 \%)$ & $11(52 \%)$ & $\underline{0.78}$ \\
\hline
\end{tabular}

B-Eos, blood eosinophils; ppb, parts per billion.

Values are shown as medians (interquartile range) or number (\%).

Mann-Whitney U test, Chi-square test, or Fischer's exact test were used when appropriate. 
Table 4. Associations between bacterial finding and clinic visits due to a relapse within two months after hospitalization.

\begin{tabular}{|l|c|c|c|c|}
\hline Bacterial detection positive & $\underline{\mathbf{n}^{1}}$ & $\underline{\text { Odds ratio }}$ & $\underline{\mathbf{9 5 \%} \text { CI }}$ & $\underline{\boldsymbol{P}}$ \\
\hline$\underline{\text { Nasopharyngeal bacterial culture }}$ & $\underline{51}$ & $\underline{7.27}$ & $\underline{1.43,36.94}$ & $\underline{0.017}$ \\
\hline$\underline{\text { Bacterial serology }}$ & $\underline{90}$ & $\underline{1.39}$ & $\underline{0.39,4.99}$ & $\underline{0.62}$ \\
\hline$\underline{\text { Urine pneumococcal antigen }}$ & $\underline{92}$ & $\underline{0.93}$ & $\underline{0.32,2.71}$ & $\underline{0.89}$ \\
\hline$\underline{\text { Any bacterial detection method }}$ & $\underline{97}$ & $\underline{2.30}$ & $\underline{0.91,5.86}$ & $\underline{0.080}$ \\
\hline
\end{tabular}

CI, confidence interval.

Univariable regression analysis.

${ }^{1}$ The numbers for those completing the 2-month follow-up. 


\section{Legends to the figures}

Figure 1. Study flow chart.

Figure 2. A. The Kaplan-Meier plot of the hospitalization time in the first-time wheezing children with positive (bolded line) and negative nasopharyngeal bacterial culture (dashed line). Univariable hazard ratio $2.38 ; 95 \%$ confidence interval 1.32, 4.36. B. Time to recurrent wheezing (i.e. 3 physician confirmed wheezing episodes) within 12 months in the first-time wheezing children with positive (bolded line) and negative nasopharyngeal bacterial culture (dashed line). Univariable hazard ratio $1.46 ; 95 \%$ confidence interval 0.50, 4.28. C. Time to recurrent wheezing within 12 months in the first-time wheezing children with positive (bolded line) and negative bacterial serology (dashed line). Univariable hazard ratio 1.86; 95\% confidence interval $0.88,3.95$. See text for details. 


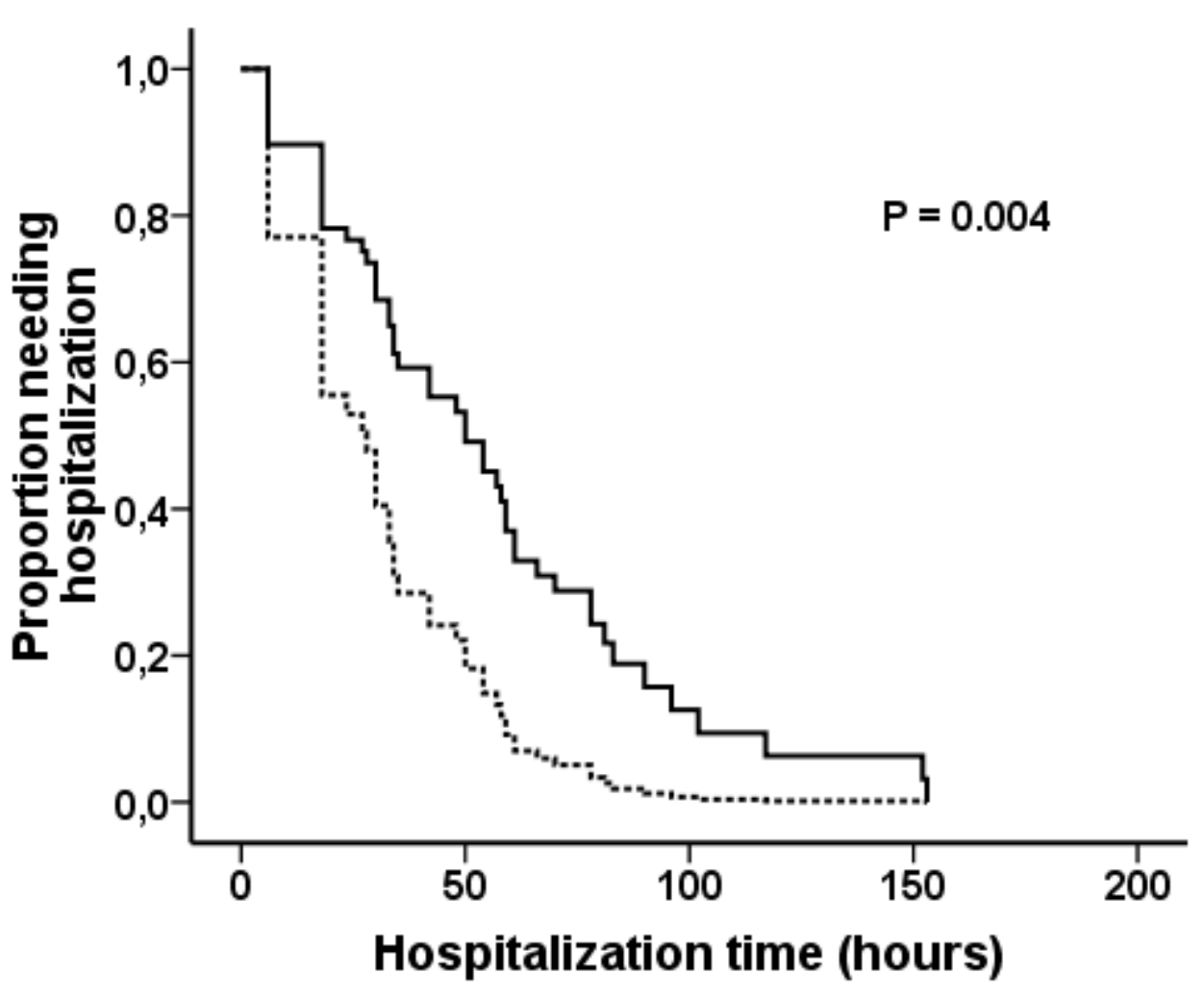




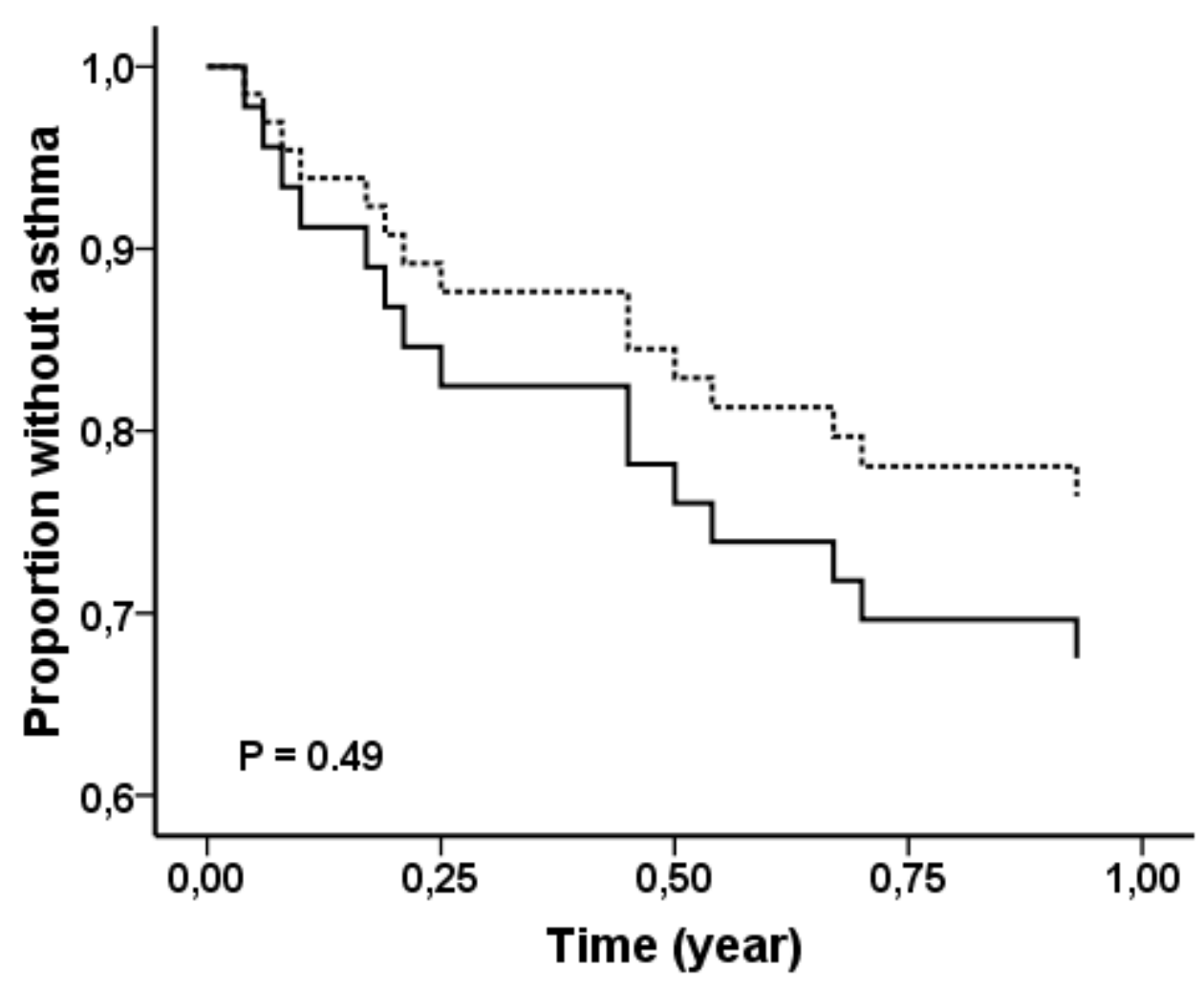




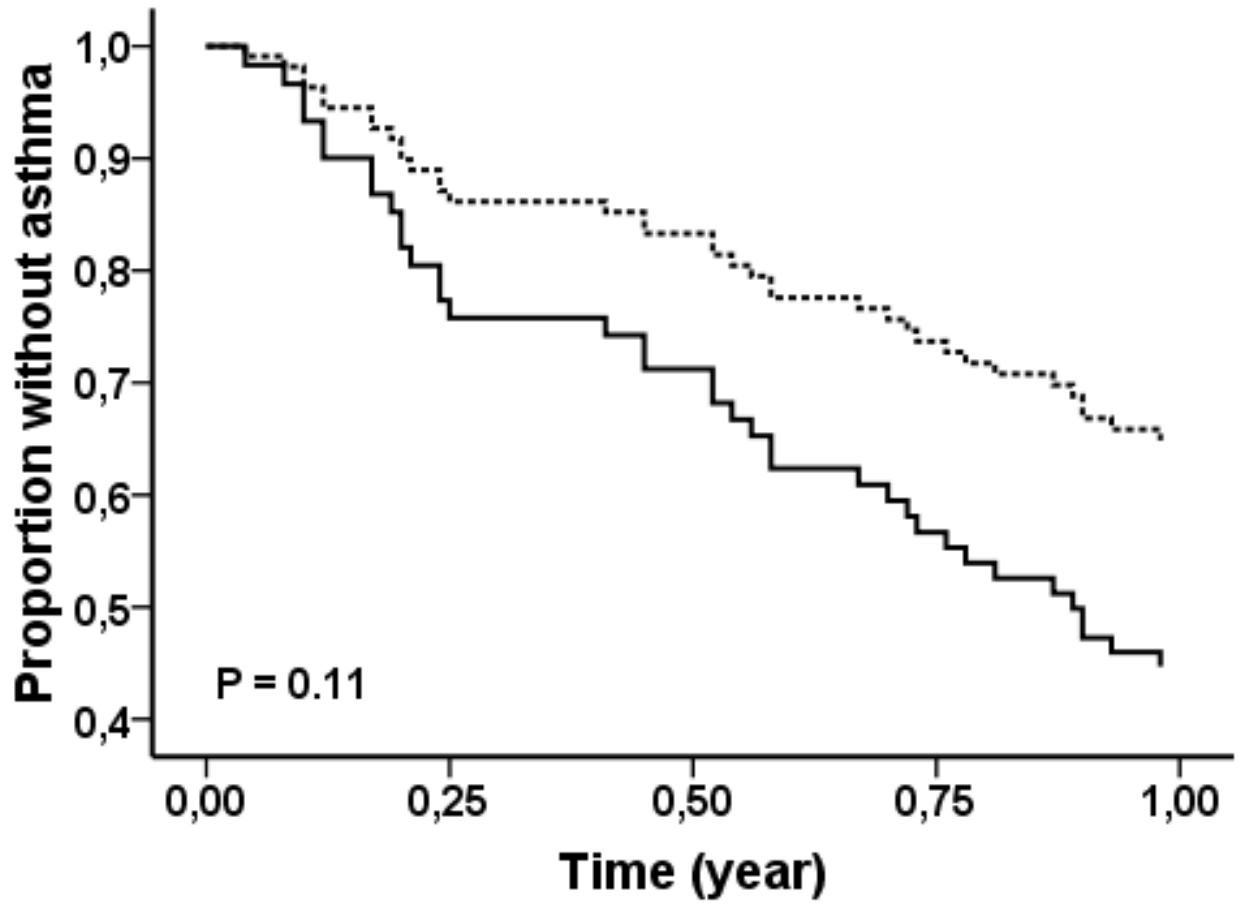

